\title{
Microbial load of some imported frozen fish species in Lagos, Nigeria
}

${ }^{* 1}$ Taiwo, I. O., ${ }^{2}$ Olopade, O. A. and ${ }^{3}$ Bamidele, N. A.

Institute of Food Security, Environmental Resources and Agricultural Research, Federal University of Agriculture, PMB 2240, Abeokuta. Nigeria

Department of Fisheries, University of Port Harcourt, Port Harcourt

Institute of Food Security, Environmental Resources and Agricultural

Research, Federal University of Agriculture

Abstract

*Corresponding E-mail: (iomtI@yahoo.com)

Freezing preserves food by stopping the growth and multiplication of microbes or by halting enzymatic activities in foods that would otherwise cause spoilage. This study was conducted to identify and profile the microbes present in frozen fish. Five frozen fish species, Trachurus trachurus, Scombers combrus, Larimichthys crocea, Gadus chalcogrammus and Oreochromis niloticus, were purchased from Ijora-Olopa frozen fish sales outlet in Lagos State and transported in ice-flakes to the laboratory for microbiological analysis of the skin, muscles and gills. S. scombrus and G. chalcogrammus had the highest (5.30 x $\left.10^{2} \mathrm{cfu} / \mathrm{g}\right)$ and lowest microbial loads $\left(1.85 \times 10^{2} \mathrm{cfu} / \mathrm{g}\right)$ respectively. The result however showed that $L$. crocea and $G$. Chalcogrammus were noticed to be significantly different $(P<0.05)$ for coliform count on both the skin and the gills. These values were much higher than the recommended public health and safety standard values that ranged from $5.0 \times 10^{5}$ and $1.0 \times$ $10^{6} \mathrm{CFUg}^{-1}$, approved by Nigerian National Agency for Drug Administration and Control (NAFDAC). Hence, it is necessary that frozen foods should be properly cooked before consumption and effective hazard analysis and critical control points implemented. The predominant bacteria species isolated were Bacillus subtilis, Pseudomonas sp., Staphylococcus aureus, E. Coli and Salmonella sp while the predominant fungal species isolated were Apergillus flavus, A. fumigatus, A. niger and Yeast.

Keywords: Frozen fish, gills, muscles, skin, bacteria, fungi,

\section{Introduction}

Nigeria is one of the largest importers of fish and fishery products in Africa (Akande, $2000)$, this probably was due to the need to meet the short fall in domestic demand for fish. Fish is one of the cheapest sources of animal protein in Africa (The World Fish Center, 2009). It is one of the main food components of humans for many centuries and still constitutes an important part of the diet of many countries. The advantage of fish as a food is due its easy digestibility and high nutritional value. Since $70 \%$ of the earth's surface is covered by water, there are plenty sources to harvest fish from. Fishes are found in different waters. Some are found in fresh water while some are found in salt water (sea and oceans). However, the type of microorganism found associated with a particular fish depends on the water it was caught (Claucas and Ward, 1996).

Kvenberg (1991) and Rodricks (1991) classified the bacteria pathogens associated with fish into two: the non-indigenous bacteria pathogen and the indigenous bacteria pathogens. The non-indigenous pathogen contaminate fish or fish's habitat in one way or the other and the pathogens include Clostridium botulinum, Listeria monocytogenes, Staphylococcus aureus, Salmonella species, Shigella species, Escherichia coli, etc. The indigenous bacteria pathogens are those naturally living in the fish's habitat. They are the Vibrio 


\section{Microbial load of imported frozen fish, Lagos, Nigeria}

species, Aeromonas species etc. Claucas and Ward (1996) also listed some organisms like S. aureus, Salmonella, Vibrio parahaemolyticus, Monocytogenes, Shigella, Aeromonas, Yersenia and Pseudomonas that could cause food-borne diseases when present in ready-to-eat sea foods.

Fishes have high water content and freeze between temperatures of 0 and $3^{\circ} \mathrm{C}$ with an average of about $2^{\circ} \mathrm{C}$ (Desrosier, 1978). Freezing kills some bacteria, but the ones not killed will grow once the fish thaws. Some bacteria such as Pseudomonas species, Moraxella species, Alcaligenes species, Flavobacterium species survive freezing temperature and will resume growth when thawed. At a temperature of $3^{\circ} \mathrm{C}$ or above, species of Clostridium botulinum can survive freezing and may grow and produce toxins (Frazier and Westhoff, 1988). The fish could be contaminated after being caught or during transportation to retail markets. After contamination and replication of microorganisms, decay occurs and the consumption becomes dangerous ( $\mathrm{Mol}$ and Tosun, 2011; Alparslan et al., 2014). Aspergillus flavus is a fungus that was first recognized to cause aflatoxicosis in domestic animals and is the most important aflatoxin-producing species in food on a global basis.

FAO (1989) observed that fishes become contaminated at sea prior to freezing due to difficulty in designing the plant that would be able to operate satisfactorily at all time in adverse weather conditions at sea. The report further indicated that the method of catching fish contributes to the bacterial load of frozen fish and observed that trawling of fish net along the bottom sediments of water for a long time could result in exposing the fish to high bacterial contamination.
Fish quality is influenced by many factors as the source, cooling methods, processing, packaging and storage conditions. The quality and freshness of fish are rapidly deteriorated through microbial and biochemical mechanisms (Al-Jasser and Al-Jasass, 2014).Freezing preserves food for extended periods by stopping the growth and multiplication of microorganisms that cause both food spoilage and food borne illness and by halting the foods own enzyme activity that would otherwise cause the food to rot. Most pathogens do not multiply at freezer temperature. Also, pathogens need water to grow and freezing turns the available water into solid ice crystals. Freezing is a common practice in the meat, fish and other animal protein based industry, because it preserves the quality for an extended time and offers several advantages such as insignificant alterations in the product dimensions, and minimum deterioration in products colour, flavour and texture (Obuz and Dikeman, 2003; USDA Food Safety Information, 2013).

Frozen fish constitutes $45 \%$ of fish consumed in Nigeria (Tobor, 1984) and with the ever growing population and the need to store and transport the food (fish) from one place to another, food preservation becomes very necessary in order to increase its shelf life and maintain its nutritional value, texture and flavour. This study was therefore undertaken to assess the microbial load of five imported frozen fish species by identifying and isolating the pathogenic bacteria and fungal load.

\section{Materials and methods Culture media}

Different media used for culturing were prepared and used, which are Nutrient Agar, MacConkey Agar, Salmonella-Shigella Agar and Potato Dextrose agar (PDA) for 


\section{Taiwo, Olopade and Bamidele}

fungi growth.

Preparation of samples and enumeration of microorganisms

The fish samples were surface sterilized separately in $3.5 \%$ sodium hypochlorite solution (w/v) with constant agitation for 7 minutes, rinsed thoroughly with sterile distilled water until the traces of hypochlorite were removed and blotted dry. The skins, muscles and the gills of the fish samples were pulverized separately using a blender. $5 \mathrm{~g}$ were taken from each sample into sterile bottles containing $450 \mathrm{ml}$ of sterile peptone physiological saline to form stock cultures. The sample bottles were placed on a rotator shaker at 120 RPM for 1 hour. 10-fold dilutions were subsequently prepared with peptone physiological saline. Aerobic mesophilic bacteria were enumerated on plate count agar at $37^{\circ} \mathrm{C}$ for 24 hours and reported as total viable count (TVC). Coliform were enumerated on MacConkey agar (MA) and incubated at $30^{\circ} \mathrm{C}$ for 48 hours. Presumptive E. coli were enumerated on MacConkey agar (MA) and incubated at $44^{\circ} \mathrm{C}$ for 48 hours. Moulds were enumerated on Potato dextrose agar (PDA) and incubated at $25^{\circ} \mathrm{C}$ for 72 hours (Felix et al., 2007).

\section{Estimation of bacteria load}

The bacteria load was estimated using the method described by Felix et al.(2007) for microbial count and involves the preparation of serial dilution and the prepared plates were inoculated in duplicate with $0.1 \mathrm{ml}$ of the $\left(10^{-2}\right.$ to $\left.10^{-5}\right)$ dilutions using pour plate method these were incubated at $37^{\circ} \mathrm{C}$ for $24 \mathrm{hr}$.

\section{Calculation of bacteria counts}

The method described by Collins et al. (1989) for estimating bacteria counts was used to enumerate the total viable counts of the isolates. Countable plates showing 1 to 32 colonies were selected and counted. The mean colony count on the pour plate of each given dilution was used to estimate the total viable count for the samples in colony forming units per gram $\left(\mathrm{CFUg}_{-}{ }^{1}\right)$. The mean colony forming unit per gram ( $\left.\mathrm{CFUg}^{-}{ }^{1}\right)$ denoted by (x) was calculated as $\Sigma f \chi / \Sigma f$, where $\Sigma f x$ is the sum of the products of number of colonies and the colony forming unit per gram; while $\Sigma \mathrm{f}$ is the summation of the number of colonies.

\section{Identification of bacteria}

Inocula were aseptically transferred from each slide into plates of respective media using a streak plate technique. The isolates were purified by repeated streaking on their respective media. Bacterial plates were incubated at $37^{\circ} \mathrm{C}$ for 24 hours while fungal plates at $25^{\circ} \mathrm{C}$ for 72 hours. A $24 \mathrm{hrs}$ old culture was prepared from each plate for identification purposes.

\section{Biochemical tests}

The following biochemical tests were carried out to determine the presence of microorganisms in the samples: Catalase test, Coagulase test, Oxidase test, Indole test, Citrate utilization test. Sugar fermentation test. Other test carried out to determine the presence of bacteria were Motility test (positive result showed motile bacterium darting across the microscopic field); Urease test (Negative test retain the brown colour with no growth). Hydrogen sulphide productiontest was used in the identification of enterobacteria and also to differentiate between bacteria such as Bacteriodes and Brucella species. Methyl red test was used to differentiate enterobacteria. Voges-proskauer (VP) test was used to differentiate some enterobacteria.

\section{Preparation of frozen samples for fungi enumeration}

$10 \mathrm{~g}$ of each of the samples purchased was mashed and thoroughly homogenized in $100 \mathrm{ml}$ of sterile normal saline. To $90 \mathrm{mls}$ of sterile distilled water, $10 \mathrm{ml}$ of the 


\section{Microbial load of imported frozen fish, Lagos, Nigeria}

homogenized sample was added in a sterile beaker. Then, $9 \mathrm{mls}$ of sterile physiological normal saline was dispensed each into different 10 test-tube and $1 \mathrm{ml}$ of the fish homogenized sample was transferred using a pipette into first test tube to give a dilution factor of $10^{-1}$, and serial dilution was made to the last tube while $1 \mathrm{ml}$ of the last tube was discarded. $1 \mathrm{ml}$ from $10^{-3}$ and $10^{-4}$ dilutions were plated out on Potato dextrose agar (PDA) using the pour plate method these were incubated at room temperature for $72 \mathrm{~h}$. This procedure was performed aseptically on a bench-work swabbed with methylated spirit. Also, a spirit lamp was lit to prevent contamination with micro-organisms.

\section{Identification/characterization of fungi isolates}

Fungi isolates were identified macroscopically viz: colour, texture and pigment; and microscopically viz by using lactophenol cotton blue. A drop of 95\% ethanol was placed on a microscopic slide. Using a sterile inoculating needle, a small portion of fungal growth was gently removed from midway between the colony centre and the edge. It was ensured that both the aerial and substrate (vegetative) mycelium was included in the specimen. With two dissecting needles, the fungus was gently teased so that it is thinly spread out on the mounting medium. When most of the ethanol had evaporated, a drop of lactophenol cotton blue was added and covered with cover glass. The fungus was examined microscopically.

\section{Results}

Microbial load count of the skin, muscles and gills is shown in Table 1. The predominant bacteria species isolated were Bacillus subtilis, Pseudomonas sp, Staphylococcus aureus, E. coli, Salmonella $\mathrm{sp}$ while the predominant fungal species isolated were Apergillus flavus, Aspergillus fumigatus, Aspergillus niger and Yeast (Table 2).

The microbial load count on the skin of the fish samples, total viable count was highest in $L$. crocea withmean value of $9.60 \times 10^{5}$ CFU. Both L. crocea and $G$. chalcogrammus were significantly different $(\mathrm{P}<0.05)$ from T. trachurus. Total coliform count was highest in $S$. scombrus and lowest in L. crocea with $7.45 \times 10^{2}$ and $4.55 \times 10^{2} \mathrm{cfu} / \mathrm{g}$ respectively. L. crocea and $S$. scombrus were significantly different $(\mathrm{P}<0.05)$. Total $E$. coli count on the skin was highest and lowest in $L$. crocea and $G$. chalcogrammus with mean values of $2.10 \times$ $10^{1}$ and $0.85 \times 10^{1} \mathrm{cfu} / \mathrm{g}$ respectively. $L$. crocea and $G$. chalcogrammus were significantly different $(\mathrm{P}<0.05)$ from the other species. Total Mould count of the skin was highest in $O$. niloticus and lowest in $L$. croce $a$ with mean values of 2.25 and $1.15 \mathrm{x}$ $10^{2} \mathrm{cfu} / \mathrm{g}$ respectively.

Microbial load count found in the muscle, TVC in all fish species ranged between 5.90 and $3.65 \times 10^{5} \mathrm{cfu} / \mathrm{g}$, Total Coliform Count was highest in S. scombrus and lowest in $G$. chalcogrammus with mean values of 5.30 and $1.85 \times 10^{2} \mathrm{cfu} / \mathrm{g}$ respectively. Total $E$. coli count was highest in $L$. crocea and lowest in $G$. chalcogrammus with mean values of 1.65 and $0.25 \times 10^{1} \mathrm{cfu} / \mathrm{g}$ respectively while Total Mould Count was highest in $L$. crocea and lowest in $G$. chalcogrammus with mean values of 0.95 and $0.30 \times 10^{2} \mathrm{cfu} / \mathrm{g}$ respectively.

Microbial load count on the gills, Total Viable Count in all fish species ranged between 11.40 and $5.05 \times 10^{5}$ with $L$. crocea and $G$. chalcogrammus with the highest and lowest counts respectively. Total Coliform Count was noticed to be highest in $S$. scombrus and lowest in T. trachurus with mean values of 9.00 and $3.10 \times 10^{2} \mathrm{cfu} / \mathrm{g}$ 


\section{Taiwo, Olopade and Bamidele}

respectively, Total E. coli count was noticed to be highest in $S$. scombrus and lowest in $G$. chalcogrammus with mean values of 2.70 and $0.55 \times 10^{1} \mathrm{cfu} / \mathrm{g}$ respectively. Total
Mould Count was observed to be highest in $S$. scombrus and lowest in $G$. chalcogrammus with mean value of 2.30 and $1.10 \times 10^{2} \mathrm{cfu} / \mathrm{g}$ respectively.

Table 2: Isolated microorganisms from fish species

\begin{tabular}{|c|c|c|}
\hline Fish species & Bacterial species & Fungal species \\
\hline Trachurus trachurus & $\begin{array}{l}\text { Bacillus subtilis, Pseudomonas } \mathrm{sp} \text {, } \\
\text { Staphylococcus aureus, E. coli, Salmonella } \\
\mathrm{sp}\end{array}$ & $\begin{array}{l}\text { Apergillus flavus, A. fumigatus, } \\
\text { A. niger, Yeast }\end{array}$ \\
\hline Oreochromis niloticus & $\begin{array}{l}\text { B, subtilis, Pseudomonas sp, S. aureus, E. } \\
\text { coli, Salmonella } \mathrm{sp}\end{array}$ & A. flavus, A. niger, Yeast \\
\hline Scomber scombrus & $\begin{array}{l}\text { B. subtilis, Pseudomonas sp, S. aureus, E. } \\
\text { coli, Salmonella } \mathrm{sp}\end{array}$ & $\begin{array}{l}\text { A. flavus, A. fumigatus, A. niger, } \\
\text { Yeast }\end{array}$ \\
\hline Larimichthys crocea & $\begin{array}{l}\text { B. subtilis, Pseudomonas sp, S. aureus, } \\
\text { Salmonella } \mathrm{sp}\end{array}$ & A. flavus, A. niger, Yeast \\
\hline Gadus chalcogrammus & Pseudomonas sp, S. aureus, E. coli, & A. fumigatus, A. niger, Yeast \\
\hline
\end{tabular}

\section{Discussion}

The mean viable count of the microorganisms on the skin, muscles and gills were higher than that recommended by the Nigeria Agency for Drug Administration and Control (NAFDAC). The standard recommended by NAFDAC for public health is between $5.0 \times 10^{5}$ and $1.0 \times 10^{6} \mathrm{cfu}$ g-1. According to Eze et al. (2011), the mean viable count although cannot be taken as an absolute figure. This is because the number and type of bacteria found on frozen fish is dependent on many factors, of which source of the fish is a major factor. This supported earlier report by Thatcher and Clark's (1973) that the kind and number of microorganisms found on frozen fish is dependent on the source of the fish, additional contamination introduced in the fishing boat, freezing temperature during storage, severity of freezing process with respect to lethality to microorganisms and contamination by handlers and market sellers.
The predominant bacteria species isolated are Bacillus subtilis, Pseudomonas sp, Staphylococcus aureus, E. coli, Salmonella sp. The microorganisms isolated from this studywere similar to the microorganisms reported by Olawale et al. (2005) and Oranusi et al. (2014) for both bacterial and fungal isolates which include $S$. auerus, $E$. coli, among other organisms. The presence of Bacillus sp., Salmonella sp., Shigella sp., Enterobacter sp, E. coli, Flavobacterium sp., Staphylococcus sp. reported in this study are in agreement with the findings of Adesokan et al. (2005) who reported the presence of Bacillus sp. and E. coli among other organisms and also report byEhigiator et al. (2014) onthe presence of Pseudomonas sp., E. coli, S. aureus, Bacillus sp. in the fish samples.

Coliforms are indicator organisms signifying contamination of a product by faecal matter. The presence of high bacteria and coliform in the fish samples could be a reflection of poor initial fish quality pre- 
Microbial load of imported frozen fish, Lagos, Nigeria

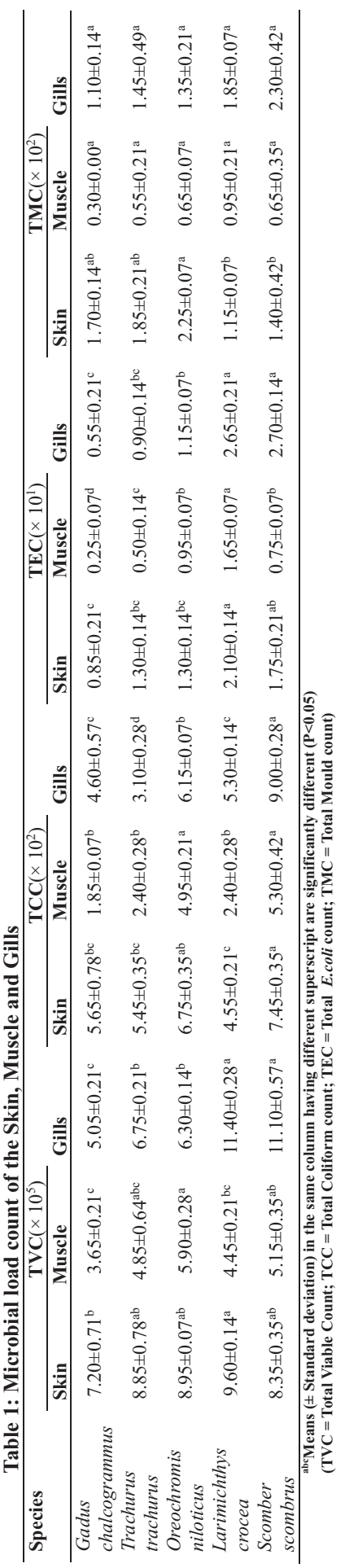




\section{Taiwo, Olopade and Bamidele}

freezing. The total coliform count of $\mathrm{T}$. trachurus was not significantly different from that recorded by Oranusi et al. (2014) while the total coliform count of $\mathrm{S}$. scombrus on the skin was higher than that reported by Oranusi et al. (2014). Previous researches by Rompre' et al. (2002) and Environmental Fact Sheet (2010) has indicated that high presence of coliform calls for concern because the presence of bacteria in this group indicated the possibility, of the presence of disease organisms in the fish samples.

The presence of $S$. aureus, Salmonella sp. and Shigella spp in fish samples also calls for concern because these are pathogenic organisms of public health concern and their significant levels in these frozen seafood products might be due to contamination of the processed frozen seafood products from the source as a result of handling by processors asimproper handling and hygiene might lead to the contamination of frozen foods and may consequently affect the health of the consumers (Dunn et al., 1995; Adebolu and Ifesan, 2001; Bankole et al., 2004; Afolabi, 2005; Omemu and Bankole, 2005; Okonko et al., 2008). The isolation and identification of these micro-organisms that are contaminants to frozen fish will help educate the public on the need to adopt various measures to prevent the multiplication of these micro-organisms. Freezing does not destroy these microorganisms, it is especially important to make sure food is wholesome before freezing. The safety of frozen foods depends on the condition and handling of the food before being frozen, and the freezing temperature.

\section{Conclusion}

The fish muscles contained less TEC and TCC count than the skin and gills. It is therefore, advisable not to eat the gills and to remove the skin of fish or properly cook fish before consumption. Frozen fish contains micro-organisms above NAFDAC recommended standard and preserving fish through freezing could reduce microbial load but not completely eliminate them. The presence of high bacteria and coliform in the fish samples indicates that the fish samples were contaminated with faecal matter. This could have occurred before the fish were frozen which could be an indication poor and unhygienic handling of captured fish species.

\section{References}

Adebolu, T. T. and Ifesan, B. O. 2001. Bacteriological quality of vegetables used in salads. Nig. J. Microbiology. 15(1): 81-85.

Adesokan, I. A., Ogunbanwo, S. T., Od e toy in bo, B. B. 2005 . Microbiological quality of selected brands of beer in Nigeria. In: the Book of Abstract of the 29th Annual Conference \&General Meeting (Abeokuta 2005) on Microbes As Agents of Sustainable Development, organized by Nigerian Society for Microbiology (NSM), University of Agriculture, Abeokuta, from 6-10 ${ }^{\text {th }} \mathrm{p}$. 21.

Afolabi, O. R. 2005. Microbial risk of hand measured re-bagged powdered milks. In: the Book of Abstract of the 29th Annual Conference \&General Meeting (Abeokuta 2005) on Microbes As Agents of Sustainable Development, organized by Nigerian Society for Microbiology (NSM), UNAAB, Abeokuta, from 6-10th November. p. 18.

Akande, G. R. 2000. Seafoods Industry in Nigeria production trends and challenges for the expert market. 


\section{Microbial load of imported frozen fish, Lagos, Nigeria}

Nigerian Institute for Oceanography and Marine Research (NIOMR). Paper NO, 107.

Al-Jasser, M. S. and Al-Jasass, F. M. 2014. Study the Chemical, Physical Changes and Microbial Growth as Quality Measurement of Fish. Annual Research and Review in Biology. 4(9): 1406-1420.

Alparslan, Y., Hasanhocaoglu, H., Metin, C. and Baygar, T. 2014. Determination of meat quality of sea bass (Dicentrarchuslabrax)sold at different selling areas. Emirates Journal of Food and Agriculture.26(3):293-301.

Bankole, M. O., Sangokoya, O. A. and Adeitan, A. A .2004. The microbiological analysis of spoilt canned foods sold and meant for sale in the markets. In: the Book of Abstract no. 67 of the $1 \mathrm{st}$ International Conference on Science and National Development, organized by COLNAS, UNAAB, from 25-28th October. p. 62.

Claucas, I. J. and Ward, A. R. 1996. Postharvest fisheries development: A guide to handling, preservation, processing and quality. Charthan, Maritime, Kent ME4 4TB, United Kingdom.

Collins, C. H., Lyne, P. M. and Grange, G. M. 1989. Microbiological Methods. 6th Ed. Butterwoths. London. 56-66 pp

Desrosier, N. W. 1978. The Technology of Food Preservation 3rd Ed., Colombia University Press, Colombia.

Dunn, R. A., Hall, W. N., Altamirano, J. V., Dietrich, S. E., Robinson-Dunn, B. and Johnson, D. R. 1995. Outbreak of Shiegellaflexnerilinked to salad prepared at a central commissary in Michigan. Public Health Reports. 110 (5): 580-586.

Ehigiator, F. A. R., Akise, O. G. and Eyong, M. M. 2014. Bacteria and fungi load of raw processed shrimp from different meat shops in Benin metropolis. Nigerian Journal of Agriculture, Food and Environment. 10(3):1-7.

Environmental fact sheet. 2010. Interpreting the Presence of Coliform Bacteria in Drinking Water, http://des.nh.gov/organization/divisi ons/water/dwgb/index.htm

Eze, E. I., Echezona, B. C. and Uzodinma, E. C. 2011. Isolation and identification of pathogenic bacteria associated with frozen mackerel fish (Scomberscombrus) in a humid tropical environment. African Journal of Agricultural Research. 6(8): 1947-1951.

Felix, M., Ramirez, E. E. and Yeannes, M. I. B. (2007).Identification of microorganism in salt used in process of food conservation. Biocell,v. 31(1): 120.

Food and Agriculture Organization (FAO). 1989. Food Safety Regulations Applied to Fish by the Major Importing Countries. FAO Fisheries Circular No 825 FAO, Rome.

Frazier, W. C. and Westhoff, D. C. 1988. Food Microbiology, 7th edition. Chapman publisher Mcgraw-Hill Book Company New-York. pg 111121

Kvenberg, E. J. 1991. Non-indigenous bacterial pathogen. In: Donn, R., Cameron, H., Van Nostrand, R. (Eds), Microbiology of Marine Food Products, New York, Pp. 263291.

Mol, S. and Tosun, S. Y. 2011. The quality of fish from retail markets in Istanbul, 


\section{Taiwo, Olopade and Bamidele}

Turkey. Journal of Fisheries Sciences.com 5(1): 16-25.

Obuz, E. and Dikeman, M. E. 2003. Effect of cooking beef muscle from frozen or thawed states on cooking traits palatability.Meat Science. 65: 993997.

Okonko, I.O., Ogunjobi, A.A., Fajobi, E.A., Onoja, B.A., Babalola, E.T and Adedej i, A.O.2008. Comparative studies and microbial risk assessment of different Readyto-Eat (RTE) frozen sea-foods processed in Ijoraolopa, Lagos State, Nigeria. Afr. J. Biotechnol. 7(16): 2898-2901.

Olawale, A. K., Oluduro, A. O. and Famurewa, O. 2005. Evaluation of microbiological and sanitary standards of canteens and eateries in Osun State Polytechnic, Iree. In: Book of Abstract of the $29^{\text {th }}$ Annual Conference \& General Meeting (Abeokuta 2005) on Microbes as Agents of Sustainable Development. Nigerian Society for Microbiology (NSM). p.19.

Omemu, A. M. and Bankole, M. O. 2005. Ready-to-eat (RTE) vegetable salad: Effect of washing and storage temperature on the microbial quality and shel-life. In: the Book of Abstract of the 29th Annual Conference \& General Meeting (Abeokuta 2005) on Microbes As Agents of Sustainable Development, organized by Nigerian Society for Microbiology (NSM), UNAAB, from 6-10th November. p. 28.

Oranusi, S., Obioha, T. U. and Adekeye, B. T. 2014. Investigation on the microbial profile of frozen foods: Fish and Meat. International Journal of Advanced Research in Biological Sciences. 1(2): 71-78.
Rodricks, E. G. 1991. Indigenous pathogen: Vibrionaceae of microbiology of marine food products, Reinhold, New York, Pp. 285295.

Rompre', A., Servais, P., Baudart, J., DeRoubin, M. R. and Laurent, $P$. (2002). Detection and enumeration of coliforms in drinking water: current $\mathrm{methods}$ and e merging a p proaches.Journal of Microbiological Methods. 49: 31-54.

Thatcher, F. S. and Clark, D. S. 1973. Microorganisms in Food: Their Significance and methods of enumeration. J. Royal Soc. Promo. Health Com. Count. 90(2): 120.

The World Fish Center. 2009. Fish Supply and Food Security for Africa. 4pp. http://pubs.iclarm.net/resource_centr e/WF 2466.pdf

Tobor, J. G. 1984. A Review of the Fishing Industry in Nigeria and status of Fish Preservation Methods and the Future growth Prerequisites to cope with Anticipated Increase in production, NIOMR Tec. Pap. No. 17

USDA Food Safety Information. 2013. Freezing and Food Safety, ht t p : / / w w w. f s i s.usd a. gov/wps/wcm/connect/cce745c90 f c $9-4$ c e 6 - a 50 c 84363e5b5a48/Freezing and_Food Sa fety.pdf?MOD=AJPERES.

Received: $17^{\text {th }}$ February, 2017 Accepted: $21^{\text {st }}$ June, 2017 